\title{
The prognosis of cancer patients undergoing liposomal doxorubicin-based chemotherapy: a systematic review and meta-analysis
}

\author{
Kaiping Zhang ( $\nabla$ zkp306@sina.com ) \\ Anhui Provincial Children's Hospital \\ Zhi Sun \\ tongling people hospital \\ Yin Zhang \\ Anhui Provincial Children's Hospital \\ Chaozhao Liang \\ the first affiliated hospital of anhui medical university \\ Li Zhang \\ the first affiliated hospital of anhui medical university \\ Min Chao \\ Anhui Provincial Children's Hospital
}

\section{Research article}

Keywords: Doxorubicin, Liposome, Nanomedicine, Chemotherapy, Prognosis, Meta-analysis.

Posted Date: July 3rd, 2019

DOI: https://doi.org/10.21203/rs.2.10907/v1

License: (c) (i) This work is licensed under a Creative Commons Attribution 4.0 International License. Read Full License 


\section{Abstract}

Background It is well known that liposome-based delivery of cytotoxic chemotherapeutics has been proposed as a putative strategy to enhance drug tolerability and efficacy compared to the conventional chemotherapy. However, its potential effects on improving cancer patients prognosis remain largely unknown. The current meta-analysis is to explore the prognosis of cancer patients undergoing liposomal doxorubicin-based chemotherapy. Methods A detailed review of English and Chinese literature was conducted from PubMed, Embase, Cochrane Library, China Biology Medicine disc (CBM), China National Knowledge Infrastructure (CNKI) up to March 21st, 2019. We evaluate its possible correlations using hazard ratios (HRs) with 95\% confidence intervals (Cls). The pooled data were calculated by STATA software and Review Manager 5.3 software. Results Consequently, 26 studies including 7943 patients were satisfied in current analysis. We found that there were no significant differences between liposomal and conventional chemotherapy in OS (HR=0.98, 95\% Cl: 0.93-1.04, $\mathrm{P}=0.544)$ and PFS (HR=1.00, 95\%Cl: 0.92-1.10, $\mathrm{P}=0.945)$. Likewise, subgroup-analysis regarding country, cancer type and sample sizes also showed the similar results of the two paired groups. Conclusion Taken together, our findings have demonstrated that there was no association of undergoing liposomal doxorubicin-based chemotherapy with cancer prognosis. However, detailed and further studies are needed to confirm these conclusions.

\section{Background}

Generally, patients with malignant diseases often have worse psychological and physical health. An estimation of 2018 cancer statistics revealed about 1,735,350 new cancer cases diagnosed and 609,640 new deaths assigned to cancer in US [1]. Although we have made enormous progress against cancer in the past decade, chemotherapy is of great importance for majority of the patients especially the late-stage patients. However, most patients treated with conventional chemotherapy suffer from serious side effects due to non-selective toxicity of chemotherapeutic drugs to normal cells [2]. There is an urgent need and tremendous value to develop novel chemotherapeutic drug carriers.

Advanced researches indicate that nano-sized carriers have presented a important therapeutic agents in both diagnosis and therapy of cancer because they have longer plasma half-life and may enhance chemotherapeutic drugs delivery while limiting non-tumorous tissue distribution [3]. Consequently, it possesses increase anticancer efficacy and lower toxicity to normal tissue [4]. To date, pegylated liposomal doxorubicin (PLD; Doxil/Caelyx) is unique formulation of doxorubicin, which is confined in liposomes. It is a cytotoxic anthracycline antibiotic extracted from Streptomyces peucetius var. Caesius [5, 6]. PLD is the first FDA-approved anticancer nano-drug and has demonstrated tremendous benefits compared to conventional chemotherapy. However, the possible mechanism of its anti-tumor has not been explained clearly. It may interfere with the DNA, RNA, and protein synthesis by blocking topoisomerase I and intercalate between adjacent base pairs of the double helix structure of DNA [7, 8]. Despite the well-established role of liposomal doxorubicin-based chemotherapy in prognosis for tumor patients, these conclusions were the focuses of controversy. Meta-analysis is a statistical software that incorporates all available data to derive a pooled and authentic result [9]. Herein, we try to perform a meta-analysis to explore whether cancer patients undergoing liposomal doxorubicin-based chemotherapy is associated with cancer prognosis, which efforts may make a contribution to the clinical therapy.

\section{Methods}

\section{Literature search strategy}


A detailed review of English and Chinese literature was conducted from PubMed, Embase, Cochrane Library, CBM, CNKI, using the terms ( "liposom* and doxorubicin OR DOX-SL OR Lipodox OR Doxil OR Caelyx OR Lipo-Dox OR DaunoXome") and ("cancer OR tumor OR tumour OR neoplasm OR neoplasma OR neoplasia OR carcinoma"). The literature search was last updated on March $21^{\text {st }}, 2019$. We also searched the reference of the relevant review articles to seek for the potentially included studies. We did not try to contact the corresponding authors if the survival analysis data could not obtained. The PRISMA statement for reporting systematic reviews and meta-analyses was cited in this meta-analysis [10]. In addition, the ethical approval was not applied in current study because there was no patient's privacy or clinical samples.

\section{Inclusion and exclusion criteria}

Relevant studies should meet the following criteria before being included: (1) the included studies focused on the association of cancer patients undergoing liposomal doxorubicin-based chemotherapy with prognosis; (2) the studies provided survival analysis data of $\mathrm{HR}$ and $95 \% \mathrm{Cl}$ or a survival curve from which we could extract the $\mathrm{HR}$, 95\% Cl; As per the exclusion criteria: (1) no survival analysis data; (2) studies involved cell lines and animals; (3) similar or duplicate study; (4) other type articles including reviews, case reports, letters.

\section{Data extraction and quality assessment}

We extracted the relevant data including author, publication year, country, no of patients, age, cancer type, treatment arms, phase, follow-up time, survival outcomes and $\mathrm{HR}(95 \% \mathrm{Cl})$ from included study. The data were independently extracted by 2 authors (Kaiping Zhang and Zhi Sun). Disagreements were resolved by discussion or reviewed by a third author (Min Chao).

Among the relevant data, country came from USA, UK, Greece and others; Sample size was separated into $\geq 100$ and <100; Cancer type included soft tissue sarcoma (STS), multiple myeloma (MM), acute myelogenous leukaemia $(A M L)$, non-small cell lung cancer (NSCLC), oesophago-gastric (OG) cancer, acute lymphoblastic leukemia (ALL), metastatic breast cancer (MBC), ovarian cancer (OG). Survival outcomes contained overall survival (OS) and progression-free survival (PFS). The quality of included studies was assessed with the Newcastle-Ottawa Scale (NOS), which is composed of three domains: selection, comparability, and exposure. The NOS is a semi-quantitative scale, from which a score of 0-9 was assigned to each study. A total score of $\leq 3$ was considered poor quality, 4-6 was considered moderate qualify, and 7-9 was deemed high quality.

\section{Statistical analysis}

We explored the prognosis of cancer patients undergoing liposomal doxorubicin-based chemotherapy by using Review Manager 5.3 (Cochrane Collaboration, Oxford, UK) and STATA 12.0 software (Stata Corpotation, College Station, TX). HR(95\% Cl) was obtained for assessing the prognosis of cancer patients after liposomal doxorubicinbased chemotherapy. Meanwhile, the $\mathrm{Q}$ statistics and $\mathrm{I}^{2}$ test were applied to calculate the heterogeneity of eligible study. $P<0.05$ and/or $I^{2}>50 \%$ were considered as statistically heterogeneous, and random effects (DerSimonian and Laird method) model was used to pool the results [11, 12]. Otherwise, fixed effects (Mantel-Haenszel method) model was applied [13].

One-way sensitivity analyses removed each included studies were performed to assess the pooled results' stability. Moreover, the publication bias was assessed using Begg's test. $P<0.05$ indicated that there was a bias of this metaanalysis [14]. Additionally, different subgroups consisted of country, cancer type and sample size were analysed in current meta-analysis. 


\section{Results}

\section{Study characteristics}

Consequently, 26 studies with a total of 7943 participants were selected in our meta-analysis (Fig. 1) [15- 40]. The main study characteristics are provided in Table 1. Among them, Kaye's phase II, open-Label, randomized, multicenter study was performed to explore three different chemotherapy in ovarian cancer [29]. Therefore, we took it as three different studies independently. At length 28 studies were included in this analysis (Table 1).

Among these studies, 27/28 studies came from English database and 1/28 was conducted in the People's Republic of China. The participants of each included studies ranged from 60 to 973 . The cancer types contained $9 \mathrm{MBC}, 10$ OC, 3 NSCLC, 2 MM, 1 ALL, 1 AML, 1 OG cancer and 1 STS. Meanwhile, 26 and 27 out of 28 studies reported OS and PFS, respectively. The detailed information about the involved studies and patients is presented in Table 2. However, the treatment arms differed greatly in these eligible studies .

\section{Meta-analysis of OS}

As a result, 26 were had analysed the prognosis of cancer patients undergoing liposomal doxorubicin-based chemotherapy. We found that no significant differences was explored between two paired groups in $0 S(H R=0.98$, 95\% Cl: 0.93-1.04, $P=0.544$ ) (Fig. 2). Likewise, subgroup analysis demonstrated no significant difference regarding country, cancer type and sample sizes (Table 3).

\section{Meta-analysis of PFS}

There were 27 studies involved with PFS. Ultimately, we found that no association of patients after liposomal chemotherapy in tumors was detected with PFS (HR=1.00, 95\% Cl: 0.92-1.10, $P=0.945)$ (Fig. 3). There was no significantly statistical differences in different subgroup analysis rather than subgroup of country and cancer type. The detail were shown in Table 4.

\section{Sensitivity analysis and Publication bias evaluation}

Sensitivity analysis by deleting each single study at a time was performed to assess the reliability of the pooled results. It demonstrated that our conclusions were relatively stable between two paired groups in OS (Figure 4) and PFS (Fig. 5). Furthermore, Begg's funnel plot was used to detect the publication bias of the eligible studies, and observed no publication bias in this analysis of OS (P=0.508) (Fig. 6A) and PFS ( $P=0.983)$ (Fig. 6B, respectively).

\section{Discussion}

Although cancer is not completely curable by current therapies, it deserves effective treatment. Patients receiving proper chemotherapy would help to relieve the symptom, improve the quality of life (QoL), and prolong survival. However, conventional chemotherapy can not satisfy people's demands. After persistent efforts over the recent years, many anticancer nanoplatforms have been explored and investigated in preclinical and clinical trials. Yet, only the minority has satisfied efficacy criteria for regulatory approval, and many liposomal platforms were applied [41].

Doxorubicin is generally regarded as the most effective anticancer drugs, but its clinical practice has limitation because of a cumulative dose-dependent cardiotoxicity that could result in some potentially fatal toxicity of nontarget normal tissues. PLD is a active and unique formulation of doxorubicin, which has been proven to be a better 
therapeutic choice for cancer patients. In this formulation, doxorubicin-encapsulated liposomes are sterically stabilized by grafting polyethylene glycol onto the liposomal surface (Stealth Liposome) [42]. Its liposomal encapsulation reduces plasma free anticancer drug level and drug delivery to normal tissues, possibly decreasing immunosupression and cardiotoxicity of doxorubicin [43]. It confers different pharmacokinetic characteristics that results in a circulation half-life compared with conventional free doxorubicin, which has a half-life of less than 10 minutes [44]. Then prolonged circulation in cancer tissues permits higher uptake of PLD. The selective accumulation of PLD in cancer tissue led to about 10-fold higher intracellular anticancer drug concentrations than adjacent normal tissues [45]. Consequently, patients who have received PLD reduced risk of nausea or vomiting, myelosuppression, alopecia, and cardiotoxicity $[46,47]$. In addition, acquisition of drug resistance of tumor cells in patients is a major challenge in previously treated patients, which could be explained by the barrier of the chemotherapy drug transport across the cell membrane. PLD directly fused with the tumor cell membrane rather than transporting across the cell membrane. Accordingly, PLD was gradually considered the most appropriate chemotherapeutic agents for the cancer patients, especially for resistant tumors [48].

In general, PLD has substantial clinical activity of durable clinical responses in $26 \%$ of patients [49]. Recent researches have shown that PLD may prolong both PFS and OS when compared with conventional chemotherapy. Because of these relatively small sample size trials, the results can not be considered definitive. This meta-analysis was performed to explore the prognosis of cancer patients after liposomal doxorubicin-based chemotherapy in various tumors. As results, PLD has not shown significant superiority to other approved conventional chemotherapy drugs in prognosis. No association was detected between liposomal vs. conventional formulations in OS and PFS. Subgroup analysis also showed that there was no statistical difference rather than subgroups of country and cancer type in PFS. However, these results remains to be further evaluated in advanced research. The previously reported studies would suggest that we need to take dose ranges and cycle dependent pharmacokinetic changes into consideration [50]. Maybe larger single doses may be more efficacious than smaller split doses [51]. Thus, detailed studies are required to confirm our conclusions.

Our study has several limitations. First, merely published studies were included for eligible literatures. Then there were inconsistent chemotherapy regimen and dose of eligible studies, and may be influenced our conclusions. Meanwhile, the extreme heterogeneity suggested that potentially possible factors should be taken into consideration. In spite of limitations mentioned above, no association of cancer patients after liposomal doxorubicin-based chemotherapy in prognosis was addressed in our study.

\section{Conclusions}

In summary, our study is the relatively detailed analysis to explore the prognosis of cancer patients undergoing liposomal doxorubicin-based chemotherapy. Our meta-analysis revealed that no association was found in overall population as well as the corresponding subgroups. Further clinical studies are required to confirm our conclusion in cancer patients.

\section{Abbreviations}

PLD: pegylated liposomal doxorubicin; HR: hazard ratio; Cl: confidence interval; OS: overall survival; PFS: progression-free survival; STS: soft tissue sarcoma; MM: multiple myeloma; AML: acute myelogenous leukaemia; NSCLC: non-small cell lung cancer; OG: oesophago-gastric; ALL: acute lymphoblastic leukemia; MBC: metastatic breast cancer; OC: ovarian cancer; 


\section{Declarations}

\section{Acknowledgments}

Not Applicable.

\section{Funding}

This work was supported by the National Natural Science Foundation of China (Grant nos. 81630019, 81870519), Scientific Research Fundation of the Institute for Translational Medicine of Anhui Province (Grant no. 2017ZHYX02), Cultivation Project of Young Top-Notch Talent Support from Anhui Medical University (AHMU), Funding for Distinguished Young Scientists of the First Affiliated Hospital of AHMU.

\section{Availability of data and materials}

All data generated or analyzed during this study are included in this published article.

\section{Authors' contributions}

K.P.Z. and Z.S. conceived the analysis, performed literature search, and wrote the manuscript; Y.Z. contributed to the analysis; C.Z.L., L.Z. and M.C. conceived the analysis, contributed to the analysis. All authors approved the final version of the manuscript.

\section{Ethics approval and consent to participate}

Not Applicable.

\section{Consent for publication}

Not Applicable.

\section{Competing interests}

The authors declare that they have no competing interests.

\section{References}


1. Siegel RL, Miller KD, Jemal A. Cancer statistics, 2018. CA Cancer J Clin.2018;68(1):7-30.

2. Al-Jamal WT, Kostarelos K. Liposomes: from a clinically established drug delivery system to a nanoparticle platform for theranostic nanomedicine. Acc Chem Res. 2011;44(10):1094-104.

3. Namiki Y, Fuchigami T, Tada N, et al. Nanomedicine for cancer: lipid-based nanostructures for drug delivery and monitoring. Acc Chem Res.2011;44(10):1080-93.

4. Batist G, Ramakrishnan G, Rao CS, et al.Reduced cardiotoxicity and preserved antitumor efficacy of liposomeencapsulated doxorubicin and cyclophosphamide compared with

conventionaldoxorubicin and cyclophosphamide in a randomized, multicenter trial of metastatic breast cancer. J Clin Oncol. 2001;19(5):1444-54.

5. Karimi Zarchi AA, Amini SM, Salimi A, Kharazi S. Synthesis and characterisation of liposomal doxorubicin with loaded gold nanoparticles. IET Nanobiotechnol. 2018;12(6):846-9.

6. Malla S, Niraula NP, Singh B, Liou K, Sohng JK. Limitations in doxorubicin production from Streptomyces peucetius. Microbiol Res. 2010;165(5):427-35.

7. Muggia FM. Clinical efficacy and prospects for use of pegylated liposomal doxorubicin in the treatment of ovarian and breast cancers. Drugs 1997;54(Suppl 4):22-9.

8. Alberts DS, Garcia DJ. Safety aspects of pegylated liposomal doxorubicin in patients with cancer. Drugs 1997;54(Suppl 4):30-5;

9. Munafo, M.R. \& Flint, J. Meta-analysis of genetic association studies. Trends. Genet. 2004;20(9):439-44.

10. Liberati A, Altman DG, Tetzlaff J, et al. The PRISMA statement for reporting systematic reviews and metaanalyses of studies that evaluatehealth care interventions: explanation and elaboration. J Clin Epidemiol. 2009;62(10):e1-34.

11. Higgins JP, Thompson SG. Quantifying heterogeneity in a meta-analysis. Stat Med. 2002;21(11):1539-58.

12. DerSimonian R, Laird N. Meta-analysis in clinical trials. Control Clin Trials. 1986;7(3):177-88.

13. Mantel N, Haenszel W. Statistical aspects of the analysis of data from retrospective studies of disease. J Natl Cancer Inst. 1959;22(4):719-48.

14. Begg CB, Berlin JA. Publication bias and dissemination of clinical research. J Natl Cancer Inst. 1989;81(2):10715.

15. Judson I, Radford JA, Harris M, et al. Randomised phase II trial of pegylated liposomal doxorubicin (DOXIL/CAELYX) versusdoxorubicin in the treatment of advanced or metastatic soft tissue sarcoma: a study by the EORTCSoft Tissue and Bone Sarcoma Group. Eur J Cancer. 2001;37(7):870-7.

16. Dimopoulos MA, Pouli A, Zervas K, et al. Prospective randomized comparison of vincristine, doxorubicin and dexamethasone (VAD) administered as intravenous bolus

injection and VAD with liposomal doxorubicin as first-line treatment in multiple myeloma. Ann Oncol.2003;14(7):1039-44.

17. O'Brien ME, Wigler N, Inbar M, et al. Reduced cardiotoxicity and comparable efficacy in a phase III trial of pegylated liposomal doxorubicin HCl (CAELYX/Doxil) versus conventional doxorubicin for firstline treatment of metastatic breast cancer. Ann Oncol.2004;15(3):440-9.

18. Rifkin RM, Gregory SA, Mohrbacher A, Hussein MA. Pegylated liposomal doxorubicin, vincristine, and dexamethasone provide significant reduction in toxicity compared with doxorubicin, vincristine, and dexamethasone in patients with newly diagnosed multiple myeloma: a Phase III multicenter randomized trial. 2006;106(4):848-58.

Page $7 / 20$ 
19. Hunault-Berger $M$, Leguay $T$, Thomas $X$, et al.

A randomized study of pegylated liposomal doxorubicin versus continuous-infusion doxorubicin in elderly patients with acute lymphoblastic leukemia: the GRAALL-SA1 study. 2011;96(2):245-52.

20. Batist G, Ramakrishnan G, Rao CS, et al. Reduced cardiotoxicity and preserved antitumor efficacy of liposomeencapsulated doxorubicin and cyclophosphamide compared

with conventionaldoxorubicin and cyclophosphamide in

a randomized, multicenter trial of metastatic breast cancer. J Clin Oncol.2001;19(5):1444-54.

21. Harris L, Batist G, Belt R, et al. Liposome-encapsulated doxorubicin compared with conventional doxorubicin in a randomized multicenter trial as first-line therapy of metastatic breast carcinoma. 2002;94(1):25-36.

22. Latagliata $R$, Breccia $M$, Fazi $P$, et al. Liposomal daunorubicin versus standard daunorubicin: long term followup of the GIMEMA GSI 103 AMLE randomized trial in patients older than 60 years with acute myelogenous leukaemia. Br J Haematol.2008;143(5):681-9.

23. Mylonakis N, Athanasiou A, Ziras N, et al.

Phase II study of liposomal cisplatin (Lipoplatin) plus gemcitabine versuscisplatin plus gemcitabine as first line treatment in inoperable (stage IIIB/IV) non-small cell lung cancer. Lung Cancer.2010;68(2):240-7.

24. Stathopoulos GP, Antoniou D, Dimitroulis J, et al. Liposomal cisplatin combined with paclitaxel versus cisplatin and paclitaxel in non-small-cell lung cancer: a randomized phase III multicenter trial. Ann Oncol. 2010;21(11):2227-32.

25. Yang $X$, Zhang $H$, Nong $J$, et al. A randomized trial of liposomal paclitaxel plus cisplatin as first-line therapy for advanced non-small cell lung cancer. Zhongguo Fei Ai Za Zhi. 2012;15(4):208-12.

26. Roy AC, Park SR, Cunningham D, et al. A randomized phase Il study of PEP02 (MM-398), irinotecan or docetaxel as a second-line therapy in patients with locally advanced or metastatic gastric or gastro-oesophageal junction adenocarcinoma. Ann Oncol.2013;24(6):1567-73.

27. Pignata S, Scambia G, Ferrandina G, et al.

Carboplatin plus paclitaxel versus carboplatin plus pegylated liposomal doxorubicin as first-line treatment for patients with ovarian cancer: the MITO-2 randomized phase III trial. J Clin Oncol.2011;29(27):362835.

28. Bafaloukos D, Linardou H, Aravantinos G, et al.

A randomized phase II study of carboplatin plus pegylated liposomal doxorubicin

versus carboplatin plus paclitaxel in platinum sensitive ovarian cancer patients:

a Hellenic Cooperative Oncology Group study. BMC Med.2010;8:3.

29. Kaye SB, Lubinski J, Matulonis U, et al. Phase II, open-label, randomized, multicenter study comparing the efficacy and safety of olaparib, a poly (ADP-ribose) polymerase inhibitor, and pegylated liposomal doxorubicin in patients with BRCA1 or BRCA2 mutations and recurrent ovarian cancer. J Clin Oncol.2012;30(4):372-9.

30. Alberts DS, Liu PY, Wilczynski SP, et al.

Randomized trial of pegylated liposomal doxorubicin (PLD) plus carboplatinversus carboplatin in platinumsensitive (PS) patients with recurrent epithelialovarian or peritoneal carcinoma after failure of initial platinumbased chemotherapy (Southwest Oncology Group Protocol S0200). Gynecol Oncol.2008;108(1):90-4.

31. Pujade-Lauraine E, Wagner U, Aavall-Lundqvist E, et al. Pegylated liposomal Doxorubicin and Carboplatin compared with Paclitaxel and Carboplatin forpatients with platinum-sentitive ovarian cancer in late relapse. J Clin Oncol. 2010;28(20):3323-9. 
32. Mutch DG, Orlando M, Goss T, et al. Randomized phase III trial of gemcitabine compared with pegylated liposomal doxorubicin in patients with platinum-resistant ovarian cancer. J Clin Oncol.2007;25(19):2811-8.

33. Gordon AN, Fleagle JT, Guthrie D, et al. Recurrent epithelial ovarian carcinoma: a randomized phase III study of pegylated liposomal doxorubicin versus topotecan. J Clin Oncol. 2001;19(14):3312-22.

34. Colombo N, Kutarska E, Dimopoulos M, et al. Randomized, open-label, phase III study comparing patupilone (EP0906) with pegylated liposomal doxorubicin in platinum-refractory or -resistant patients with recurrent epithelial ovarian, primary fallopian tube, or primary peritoneal cancer. J Clin Oncol.2012;30(31):3841-7.

35. Sparano JA, Makhson AN, Semiglazov VF, et al. Pegylated liposomal doxorubicin plus docetaxel significantly improves time to progression without additive cardiotoxicity compared with docetaxel monotherapy in patients with advanced breast cancer previously treated with neoadjuvant-adjuvant anthracycline therapy: results from a randomized phase III study. J Clin Oncol.2009;27(27):4522-9.

36. Chan S, Davidson N, Juozaityte E, et al.

Phase III trial of liposomal doxorubicin and cyclophosphamide compared with epirubicin and cyclophosphamide as first-line therapy for metastatic breast cancer. Ann Oncol.2004;15(10):1527-34.

37. Keller AM, Mennel RG, Georgoulias VA, et al.

Randomized phase III trial of pegylated liposomal doxorubicin versusvinorelbine or mitomycin C plus vinblastine in women with taxane-refractoryadvanced breast cancer. J Clin Oncol.2004;22(19):3893-901.

38. Baselga J, Manikhas A, Cortés J, et al. Phase III trial of nonpegylated liposomal doxorubicin in combination with trastuzumab and paclitaxel in HER2-positive metastatic breast cancer. Ann Oncol. 2014;25(3):592-8.

39. Smorenburg $\mathrm{CH}$, de Groot SM, van Leeuwen-Stok AE, et al. A randomized phase III study comparing pegylated liposomal doxorubicin with capecitabine as first-line chemotherapy in elderly patients with metastatic breast cancer: results of the OMEGA study of the Dutch Breast Cancer Research Group BOOG. Ann Oncol.2014;25(3):599-605.

40. Harbeck N, Saupe S, Jäger E, et al. A randomized phase III study evaluating pegylated liposomal doxorubicin versus capecitabine as first-line therapy for metastatic breast cancer: results of the PELICAN study. Breast Cancer Res Treat.2017;161(1):63-72.

41. Viswanadh MK, Muthu MS. Targeted bioadhesive nanomedicine: an effective approach for synergistic drug delivery to cancers. Nanomedicine (Lond). 2018;13(12):1401-3.

42. Hu Y, Wu C, Zhu C, et al. Enhanced Uptake and Improved Anti-tumor Efficacy of Doxorubicin Loaded Fibrin Gel with Liposomal Apatinib in Colorectal Cancer. Int J Pharm.2018;552(1-2):319-27.

43. Farzaneh $\mathrm{H}$, Ebrahimi Nik M, Mashreghi M, et al. A study on the role of cholesterol and phosphatidylcholine in various features of liposomal doxorubicin: From liposomal preparation to therapy. Int J Pharm. 2018;551(12):300-8.

44. Boers-Sonderen MJ, van Herpen CM, van der Graaf WT, et al. Correlation of toxicity and efficacy with pharmacokinetics (PK) of pegylated liposomal doxorubicin (PLD) (Caelyx ${ }^{\circledR}$ ). Cancer Chemother Pharmacol. 2014;74(3):457-63.

45. Symon Z, Peyser A, Tzemach D, et al. Selective delivery of doxorubicin to patients with breast carcinoma metastases by stealth liposomes. Cancer. 1999;86(1):72-8.

46. Gabizon A, Martin F. Polyethylene glycol-coated (pegylated) liposomal doxorubicin. Rationale for use in solid tumours. 1997;54 Suppl 4:15-21.

47. van den Hurk C, Breed W, Dercksen W. Nonpegylated liposomal doxorubicin: reduction in cardiotoxicity, although still severe alopecia. Anticancer Drugs. 2015;26(6):687. 
48. Boulikas T. Molecular mechanisms of cisplatin and its liposomally encapsulated form, Lipoplatin ${ }^{\mathrm{TM}}$. Lipoplatin $^{\mathrm{TM}}$ as a chemotherapy and antiangiogenesis drug. Cancer Ther. 2007;5(5):351-76.

49. Muggia FM, Hainsworth JD, Jeffers S,et al.

Phase II study of liposomal doxorubicin in refractory ovarian cancer: antitumor activity and toxicity modification by liposomal encapsulation. J Clin Oncol.1997;15(3):987-93.

50. Gabizon A, Isacson R, Rosengarten O, et al. An open-label study to evaluate dose and cycle dependence of the pharmacokinetics of pegylated liposomal doxorubicin. Cancer Chemother Pharmacol.2008;61(4):695-702.

51. Allavena P, Mantovani A. Immunology in the clinic review series; focus on cancer: tumour-associated macrophages: undisputed stars of the inflammatory tumour microenvironment. Clin Exp Immunol.2012;167(2):195-205.

\section{Tables}

Table 1 Characteristics of included clinical studies 


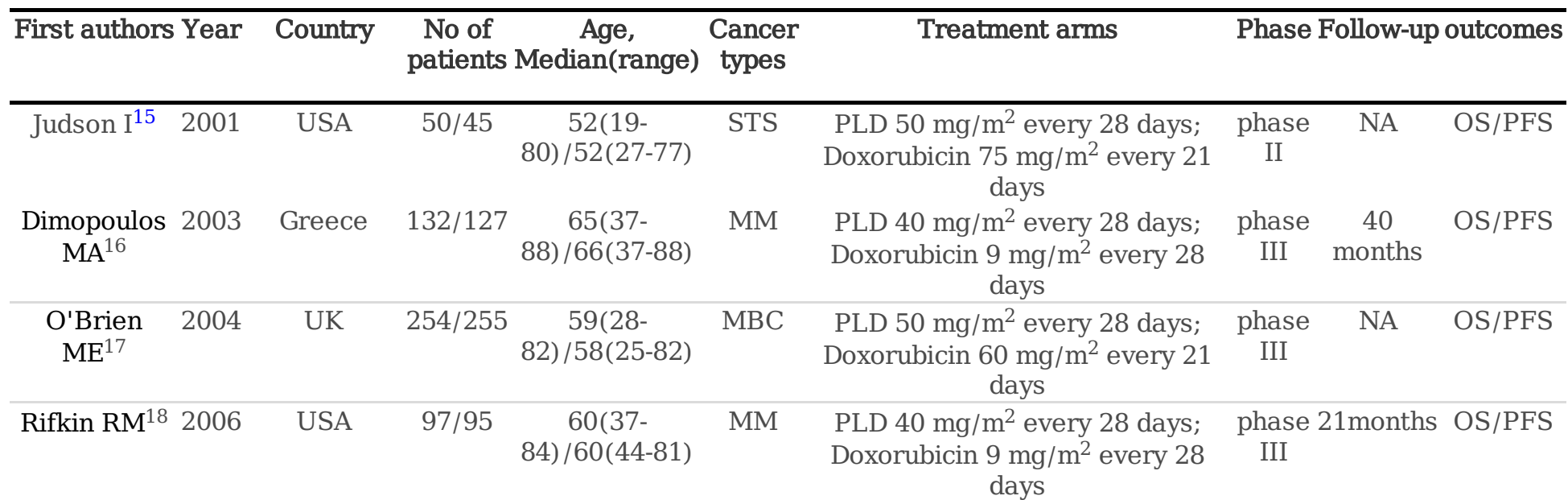

\begin{tabular}{|c|c|c|c|c|c|c|c|c|c|}
\hline $\begin{array}{l}\text { Hunault- } \\
\text { Berger } \mathrm{M}^{19}\end{array}$ & 2011 & France & $31 / 29$ & $\begin{array}{l}\text { 68(55- } \\
77) / 66(60-80)\end{array}$ & ALL & $\begin{array}{c}\text { PLD } 40 \mathrm{mg} / \mathrm{m}^{2} \text { days } 1-4 ; \\
\text { Doxorubicin } 12 \mathrm{mg} / \mathrm{m}^{2} / \text { day days } \\
1-4\end{array}$ & $\begin{array}{l}\text { phase } \\
\text { II }\end{array}$ & ths & OS/PFS \\
\hline Batist $G^{20}$ & 2001 & Canada & $142 / 155$ & $\begin{array}{l}55(30- \\
80) / 54(22-88)\end{array}$ & MBC & $\begin{array}{l}\text { Liposomal doxorubicin } 60 \mathrm{mg} / \mathrm{m}^{2} \\
\text { every } 21 \text { days; Doxorubicin } 60 \\
\mathrm{mg} / \mathrm{m}^{2} \text { every } 21 \text { days }\end{array}$ & $\begin{array}{l}\text { phase } \\
\text { III }\end{array}$ & & OS/PFS \\
\hline Harris L ${ }^{21}$ & 2002 & USA & $108 / 116$ & $\begin{array}{l}58(26- \\
85) / 58(29-82)\end{array}$ & $\mathrm{MBC}$ & $\begin{array}{c}\text { Liposomal doxorubicin } 75 \mathrm{mg} / \mathrm{m}^{2} \\
\text { every } \\
21 \text { days; Doxorubicin } 75 \mathrm{mg} / \mathrm{m}^{2} \\
\text { every } 21 \text { days }\end{array}$ & $\begin{array}{l}\text { phase } \\
\text { III }\end{array}$ & $4 \mathrm{~m}$ & OS/PFS \\
\hline $\begin{array}{l}\text { Latagliata } \\
\mathrm{R}^{22}\end{array}$ & 2008 & Rome & $148 / 153$ & $\begin{array}{c}68.2(61- \\
74.8) / 68(61- \\
74.8)\end{array}$ & AML & $\begin{array}{l}\text { Daunoxome } 80 \mathrm{mg} / \mathrm{m}^{2} \text { days } 1-3 \\
\text { Daunorubicin } 45 \mathrm{mg} / \mathrm{m}^{2} \text { days } 1-3\end{array}$ & $\begin{array}{l}\text { phase } \\
\text { III }\end{array}$ & $\begin{array}{c}26.6 \\
\text { months }\end{array}$ & OS/PFS \\
\hline $\begin{array}{l}\text { Mylonakis } \\
\mathrm{N}^{23}\end{array}$ & 2010 & Greece & $47 / 41$ & $\begin{array}{c}64(49-83) / 66 \\
(52-77)\end{array}$ & NSCLC & $\begin{array}{l}\text { Liposomal cisplatin } 120 \mathrm{mg} / \mathrm{m}^{2} \\
\text { every } 21 \\
\text { days; Cisplatin } 100 \mathrm{mg} / \mathrm{m}^{2} \text { every } \\
21 \text { days }\end{array}$ & $\begin{array}{l}\text { phase } \\
\text { II }\end{array}$ & $\begin{array}{c}53 \\
\text { months }\end{array}$ & OS/PFS \\
\hline $\begin{array}{l}\text { Stathopoulos } \\
\quad \text { GP }\end{array}$ & 2010 & Greece & $114 / 115$ & $\begin{array}{c}\text { 65(37- } \\
80) / 66(41-85)\end{array}$ & NSCLC & $\begin{array}{c}\text { Liposomal cisplatin } 200 \mathrm{mg} / \mathrm{m}^{2} \\
\text { every } 14 \\
\text { days; Cisplatin } 75 \mathrm{mg} / \mathrm{m}^{2} \text { every } 14 \\
\text { days }\end{array}$ & $\begin{array}{l}\text { phase } \\
\text { II }\end{array}$ & $\begin{array}{l}15 \\
\text { months }\end{array}$ & OS/PFS \\
\hline Yang $X^{25}$ & 2012 & China & $50 / 50$ & $\begin{array}{l}55.2(34- \\
76) / 53.2(25- \\
73)\end{array}$ & NSCLC & $\begin{array}{c}\text { Liposomal paclitaxel } 150 \mathrm{mg} / \mathrm{m}^{2} \\
\text { every } 21 \\
\text { days; Paclitaxel } 150 \mathrm{mg} / \mathrm{m}^{2} \text { every } \\
21 \text { days }\end{array}$ & NA & $\begin{array}{c}20 \\
\text { months }\end{array}$ & SS/PFS \\
\hline Roy $\mathrm{AC}^{26}$ & 2013 & UK & $44 / 44$ & $\begin{array}{c}56(38- \\
81) / 62(33-79)\end{array}$ & $\begin{array}{c}\text { OG } \\
\text { cancer }\end{array}$ & $\begin{array}{c}\text { Liposomal irinotecan } 120 \mathrm{mg} / \mathrm{m}^{2} \\
\text { every } \\
21 \text { days; Irinotecan } 300 \mathrm{mg} / \mathrm{m}^{2} \\
\text { every } 21 \text { days }\end{array}$ & $\begin{array}{l}\text { phase } \\
\text { II }\end{array}$ & $\mathrm{N}$ & $\mathrm{S} / \mathrm{PFS}$ \\
\hline Pignata S 27 & 2011 & Italy & $410 / 410$ & $\begin{array}{c}57(25- \\
77) / 57(21-77)\end{array}$ & $\mathrm{OC}$ & $\begin{array}{c}\text { carboplatin and PLD } 30 \mathrm{mg} / \mathrm{m}^{2} \\
\text { every } 3 \text { weeks; carboplatin and } \\
\text { paclitaxel } 175 \mathrm{mg} / \mathrm{m}^{2} \text { every } 3 \\
\text { weeks }\end{array}$ & $\begin{array}{l}\text { phase } \\
\text { III }\end{array}$ & $\begin{array}{c}20 \\
\text { months }\end{array}$ & OS/PFS \\
\hline $\begin{array}{l}\text { Bafaloukos } \\
\quad D^{28}\end{array}$ & 2010 & Greece & $93 / 96$ & $\begin{array}{c}62(38- \\
89) / 63(37-81)\end{array}$ & $\mathrm{OC}$ & $\begin{array}{c}\text { carboplatin and PLD } 45 \mathrm{mg} / \mathrm{m}^{2} \\
\text { every } 3 \text { weeks; carboplatin and } \\
\text { paclitaxel } 175 \mathrm{mg} / \mathrm{m}^{2} \text { every } 3 \\
\text { weeks }\end{array}$ & $\begin{array}{l}\text { phase } \\
\text { II }\end{array}$ & $\begin{array}{l}43.6 \\
\text { months }\end{array}$ & PFS \\
\hline Kaye SB-129 & 2012 & UK & $33 / 32$ & $\begin{array}{l}53.0(43- \\
81) / 58.5(45- \\
77)\end{array}$ & $\mathrm{OC}$ & $\begin{array}{l}\text { PLD } 50 \mathrm{mg} / \mathrm{m}^{2} \text { every } 28 \text { days; } \\
\text { olaparib } 200 \mathrm{mg} \text { every } 28 \text { days; }\end{array}$ & $\begin{array}{l}\text { phase } \\
\text { II }\end{array}$ & NA & OS/PFS \\
\hline Kaye SB-2 29 & 2012 & UK & $33 / 32$ & $\begin{array}{c}53.0(43- \\
81) / 53.5(35- \\
76)\end{array}$ & $\mathrm{OC}$ & $\begin{array}{l}\text { PLD } 50 \mathrm{mg} / \mathrm{m}^{2} \text { every } 28 \text { days; } \\
\text { olaparib } 400 \mathrm{mg} \text { every } 28 \text { days; }\end{array}$ & $\begin{array}{l}\text { phase } \\
\text { II }\end{array}$ & NA & OS/PFS \\
\hline Kaye SB-3 $3^{29}$ & 2012 & UK & $33 / 64$ & $\begin{array}{l}\text { 53.0(43- } \\
\text { 81)/NA }\end{array}$ & OC & $\begin{array}{c}\text { PLD } 50 \mathrm{mg} / \mathrm{m}^{2} \text { every } 28 \text { days; } \\
\text { olaparib } 400+200 \mathrm{mg} \text { every } 28 \\
\text { days; }\end{array}$ & $\begin{array}{l}\text { phase } \\
\text { II }\end{array}$ & NA & PFS \\
\hline
\end{tabular}

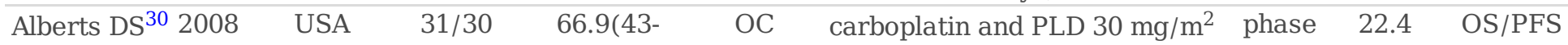


87) /62.5(31-

80)

every 4 weeks; carboplatin every III months 4 weeks

\begin{tabular}{|c|c|c|c|c|c|c|c|c|}
\hline $\begin{array}{c}\text { Pujade- } 2010 \\
\text { Lauraine } E^{31}\end{array}$ & France & $466 / 507$ & $\begin{array}{c}60.5(24- \\
82) / 61(27-82)\end{array}$ & $\mathrm{OC}$ & $\begin{array}{c}\text { carboplatin and PLD } 30 \mathrm{mg} / \mathrm{m}^{2} \\
\text { every } 4 \text { weeks; carboplatin and } \\
\text { paclitaxel } 175 \mathrm{mg} / \mathrm{m}^{2} \text { every } 3 \\
\text { weeks }\end{array}$ & $\begin{array}{l}\text { phase } \\
\text { III }\end{array}$ & $\begin{array}{c}22 \\
\text { months }\end{array}$ & OS/PFS \\
\hline Mutch DG 2007 & USA & 96/99 & $\begin{array}{c}62(28- \\
83) / 59(38-85)\end{array}$ & $\mathrm{OC}$ & $\begin{array}{c}\text { PLD } 50 \mathrm{mg} / \mathrm{m}^{2} \text { every } 28 \text { days; } \\
\text { gemcitabine } 1,000 \mathrm{mg} / \mathrm{m}^{2} \text { every } \\
21 \text { days }\end{array}$ & $\begin{array}{l}\text { phase } \\
\text { III }\end{array}$ & $\begin{array}{c}29.2 \\
\text { months }\end{array}$ & OS \\
\hline Gordon AN33 2001 & USA & $239 / 235$ & $\begin{array}{c}60(27- \\
87) / 60(25-85)\end{array}$ & $\mathrm{OC}$ & $\begin{array}{c}\text { PLD } 50 \mathrm{mg} / \mathrm{m}^{2} \text { every } 28 \\
\text { days;topotecan } 1.5 \mathrm{mg} / \mathrm{m}^{2} \text { every } \\
21 \text { days }\end{array}$ & $\begin{array}{l}\text { phase } \\
\text { III }\end{array}$ & NA & OS/PFS \\
\hline Colombo N34 2012 & Italy & $417 / 412$ & $\begin{array}{c}59(23- \\
84) / 59(25-87)\end{array}$ & $\mathrm{OC}$ & $\begin{array}{c}\text { PLD } 50 \mathrm{mg} / \mathrm{m}^{2} \text { every } 4 \text { weeks; } \\
\text { patupilone } 10 \mathrm{mg} / \mathrm{m}^{2} \text { every } 3 \\
\text { weeks }\end{array}$ & $\begin{array}{l}\text { phase } \\
\text { III }\end{array}$ & $\begin{array}{c}27 \\
\text { months }\end{array}$ & OS/PFS \\
\hline
\end{tabular}

\begin{tabular}{|c|c|c|c|c|c|c|c|c|c|}
\hline Sparano JA ${ }^{35}$ & 52009 & USA & $378 / 373$ & $\begin{array}{l}52.5(26- \\
80) / 51.8(30- \\
87)\end{array}$ & $\mathrm{MBC}$ & $\begin{array}{c}\text { PLD } 30 \mathrm{mg} / \mathrm{m}^{2} \text { and docetaxel } 60 \\
\mathrm{mg} / \mathrm{m}^{2} \text { every } 21 \text { days; docetaxel } \\
75 \mathrm{mg} / \mathrm{m} 2 \text { every } 21 \text { days }\end{array}$ & $\begin{array}{c}\text { phase } \\
\text { III }\end{array}$ & NA & OS/PFS \\
\hline Chan $\mathrm{S}^{36}$ & 2004 & UK & $80 / 80$ & $\begin{array}{c}54(19- \\
78) / 54(26-82)\end{array}$ & MBC & $\begin{array}{c}\text { Myocet } 75 \mathrm{mg} / \mathrm{m}^{2} \text { and } \\
\text { cyclophosphamide } \\
600 \mathrm{mg} / \mathrm{m}^{2} \text {; epirubicin } 75 \mathrm{mg} / \mathrm{m}^{2} \\
\text { and cyclophosphamide } 600 \mathrm{mg} / \mathrm{m}^{2} \\
\text { every } 3 \text { weeks }\end{array}$ & $\begin{array}{c}\text { phase } \\
\text { III }\end{array}$ & $\begin{array}{c}21 \\
\text { months }\end{array}$ & OS/PFS \\
\hline Keller AM ${ }^{37}$ & 2004 & USA & $150 / 151$ & $\begin{array}{c}56(33- \\
87) / 56(30-83)\end{array}$ & $\mathrm{MBC}$ & $\begin{array}{l}\text { PLD } 50 \mathrm{mg} / \mathrm{m}^{2} \text { every } 28 \text { days; } \\
\text { Vinorelbine or Mitomycin C and } \\
\text { Vinblastine every } 6 \text { to } 8 \text { weeks }\end{array}$ & $\begin{array}{c}\text { phase } \\
\text { III }\end{array}$ & NA & OS/PFS \\
\hline Baselga J38 & 2014 & USA & $181 / 182$ & $\begin{array}{c}52(22- \\
79) / 53(30-76)\end{array}$ & MBC & $\begin{array}{c}\text { NPLD } 50 \mathrm{mg} / \mathrm{m}^{2} \text { every } 3 \text { weeks } \\
\text { and trastuzumab and paclitaxel; } \\
\text { trastuzumab and paclitaxel every } \\
3 \text { weeks }\end{array}$ & $\begin{array}{c}\text { phase } \\
\text { III }\end{array}$ & $\begin{array}{c}44 \\
\text { months }\end{array}$ & OS/PFS \\
\hline $\begin{array}{c}\text { Smorenburg } \\
\mathrm{CH}^{39}\end{array}$ & & Jetherlands & $40 / 38$ & NA & $\mathrm{MBC}$ & $\begin{array}{c}\text { PLD } 45 \mathrm{mg} / \mathrm{m}^{2} \text { every } 4 \text { weeks; } \\
\text { capecitabine } 1000 \mathrm{mg} / \mathrm{m}^{2} \text { every } 3 \\
\text { weeks }\end{array}$ & $\begin{array}{c}\text { phase } \\
\text { III }\end{array}$ & $\begin{array}{c}39 \\
\text { months }\end{array}$ & OS/PFS \\
\hline Harbeck $\mathrm{N}^{4 C}$ & 2017 & Germany & $105 / 105$ & $\begin{array}{c}62(36- \\
82) / 63(22-85)\end{array}$ & $\mathrm{MBC}$ & $\begin{array}{l}\text { PLD } 50 \mathrm{mg} / \mathrm{m}^{2} \text { every } 28 \text { days; } \\
\text { capecitabine } 1250 \mathrm{mg} / \mathrm{m}^{2} \text { twice } \\
\text { daily for } 14 \text { days every } 21 \text { days. }\end{array}$ & $\begin{array}{c}\text { phase } \\
\text { III }\end{array}$ & NA & OS/PFS \\
\hline
\end{tabular}

Abbreviations: STS, Soft tissue sarcoma; MM, Multiple myeloma; AML, Acute myelogenous leukaemia; NSCLC, Nonsmall cell lung cancer; OG, Oesophago-gastric; ALL, Acute lymphoblastic leukemia; MBC, Metastatic breast cancer; OC, Ovarian cancer; NA, Not available; OS, overall survival; PFS, Progression-free survival; PLD, pegylated liposomal doxorubicin; NPLD, nonpegylated liposomal doxorubicin.

Table 2 The survival data of the selected studies 


\begin{tabular}{|c|c|c|c|c|c|c|}
\hline First authors & Year & Country & No of patient & Cancer types & outcome & $\mathrm{HR}(95 \% \mathrm{CI})$ \\
\hline Judson I & 2001 & USA & $50 / 45$ & STS & OS & $0.64(0.38-1.10)$ \\
\hline Judson I & 2001 & USA & $50 / 45$ & STS & PFS & $1.09(0.75-1.58)$ \\
\hline Dimopoulos MA & 2003 & Greece & $132 / 127$ & MM & OS & $1.36(0.85-2.17)$ \\
\hline Dimopoulos MA & 2003 & Greece & $132 / 127$ & MM & PFS & $1.15(0.80-1.64)$ \\
\hline O'Brien ME & 2004 & UK & $254 / 255$ & MBC & OS & $0.94(0.74-1.19)$ \\
\hline O'Brien ME & 2004 & UK & $254 / 255$ & MBC & PFS & $1.00(0.82-1.22)$ \\
\hline Rifkin RM & 2006 & USA & $97 / 95$ & $\mathrm{MM}$ & OS & $0.69(0.31-1.52)$ \\
\hline Rifkin RM & 2006 & USA & $97 / 95$ & MM & PFS & $1.15(0.67-1.98)$ \\
\hline Hunault-Berger $\mathrm{M}$ & 12011 & France & $31 / 29$ & ALL & OS & $0.97(0.54-1.77)$ \\
\hline Hunault-Berger $\mathrm{N}$ & 12011 & France & $31 / 29$ & ALL & PFS & $1.16(0.67-2.03)$ \\
\hline Batist G & 2001 & Canada & $142 / 155$ & MBC & OS & $1.04(0.77-1.41)$ \\
\hline Batist G & 2001 & Canada & $142 / 155$ & MBC & PFS & $1.03(0.80-1.33)$ \\
\hline Harris L & 2002 & USA & $108 / 116$ & MBC & OS & $0.76(0.56-1.04)$ \\
\hline Harris L & 2002 & USA & $108 / 116$ & MBC & PFS & $0.92(0.66-1.26)$ \\
\hline Latagliata $\mathrm{R}$ & 2008 & Rome & $148 / 153$ & AML & OS & $0.95(0.72-1.26)$ \\
\hline Latagliata $\mathrm{R}$ & 2008 & Rome & $148 / 153$ & AML & PFS & $1.10(0.80-1.50)$ \\
\hline Mylonakis N & 2010 & Greece & $47 / 41$ & NSCLC & OS & $0.92(0.54-1.56)$ \\
\hline Mylonakis N & 2010 & Greece & $47 / 41$ & NSCLC & PFS & $0.91(0.59-1.42)$ \\
\hline Stathopoulos GP & 2010 & Greece & $114 / 115$ & NSCLC & OS & $1.21(0.87-1.68)$ \\
\hline Stathopoulos GP & 2010 & Greece & $114 / 115$ & NSCLC & PFS & $0.86(0.64-1.16)$ \\
\hline Yang X & 2012 & China & $50 / 50$ & NSCLC & OS & $1.27(0.81-1.97)$ \\
\hline Yang $\mathrm{X}$ & 2012 & China & $50 / 50$ & NSCLC & PFS & $0.76(0.53-1.09)$ \\
\hline Roy AC & 2013 & UK & $44 / 44$ & OG cancer & OS & $1.32(0.79-2.21)$ \\
\hline Roy AC & 2013 & UK & $44 / 44$ & OG cancer & PFS & $1.06(0.71-1.57)$ \\
\hline Pignata S & 2011 & Italy & $410 / 410$ & OC & OS & $0.82(0.72-1.12)$ \\
\hline Pignata S & 2011 & Italy & $410 / 410$ & $\mathrm{OC}$ & PFS & $0.95(0.81-1.13)$ \\
\hline Bafaloukos D & 2010 & Greece & 93/96 & $\mathrm{OC}$ & PFS & $1.15(0.78-1.66)$ \\
\hline Kaye SB-1 & 2012 & UK & $33 / 32$ & OC & OS & $0.66(0.27-1.55)$ \\
\hline Kaye SB-1 & 2012 & UK & $33 / 32$ & $\mathrm{OC}$ & PFS & $0.91(0.48-1.74)$ \\
\hline Kaye SB-2 & 2012 & UK & $33 / 32$ & OC & OS & $1.01(0.44-2.27)$ \\
\hline Kaye SB-2 & 2012 & UK & $33 / 32$ & $\mathrm{OC}$ & PFS & $0.86(0.45-1.62)$ \\
\hline Kaye SB-3 & 2012 & UK & $33 / 64$ & OC & PFS & $0.88(0.51-1.56)$ \\
\hline Alberts DS & 2008 & USA & $31 / 30$ & OC & OS & $0.46(0.22-0.95)$ \\
\hline Alberts DS & 2008 & USA & $31 / 30$ & $\mathrm{OC}$ & PFS & $0.54(0.32-0.93)$ \\
\hline Pujade-Lauraine $\mathrm{E}$ & 2010 & France & $466 / 507$ & $\mathrm{OC}$ & OS & $0.99(0.85-1.16)$ \\
\hline Pujade-Lauraine $\mathrm{E}$ & 2010 & France & $466 / 507$ & $\mathrm{OC}$ & PFS & $0.82(0.72-0.94)$ \\
\hline Mutch DG & 2007 & USA & 96/99 & OC & OS & $1.02(0.71-1.42)$ \\
\hline Gordon AN & 2001 & USA & $239 / 235$ & OC & OS & $0.82(0.68-1.00)$ \\
\hline Gordon AN & 2001 & USA & $239 / 235$ & $\mathrm{OC}$ & PFS & $0.79(0.67-0.94)$ \\
\hline Colombo N & 2012 & Italy & $417 / 412$ & $\mathrm{OC}$ & OS & $1.07(0.91-1.26)$ \\
\hline Colombo N & 2012 & Italy & $417 / 412$ & OC & PFS & $0.95(0.8-1.12)$ \\
\hline Sparano JA & 2009 & USA & $378 / 373$ & MBC & OS & $0.98(0.82-1.17)$ \\
\hline Sparano JA & 2009 & USA & $378 / 373$ & MBC & PFS & $1.52(1.29-1.79)$ \\
\hline Chan S & 2004 & UK & $80 / 80$ & MBC & OS & $1.15(0.77-1.72)$ \\
\hline Chan S & 2004 & UK & $80 / 80$ & MBC & PFS & $1.52(1.06-2.19)$ \\
\hline Keller AM & 2004 & USA & $150 / 151$ & MBC & OS & $1.05(0.82-1.33)$ \\
\hline Keller AM & 2004 & USA & $150 / 151$ & MBC & PFS & $1.26(0.98-1.62)$ \\
\hline Baselga J & 2014 & USA & $181 / 182$ & MBC & OS & $1.27(0.98-1.65)$ \\
\hline Baselga J & 2014 & USA & $181 / 182$ & MBC & PFS & $1.19(0.92-1.53)$ \\
\hline Smorenburg $\mathrm{CH}$ & $2014 \mathrm{~N}$ & Jetherlands & $40 / 38$ & MBC & OS & $0.87(0.53-1.43)$ \\
\hline Smorenburg $\mathrm{CH}$ & $2014 \mathrm{~N}$ & Jetherlands & $40 / 38$ & MBC & PFS & $0.68(0.42-1.09)$ \\
\hline Harbeck N & 2017 & Germany & $105 / 105$ & MBC & OS & $1.12(0.79-1.58)$ \\
\hline Harbeck N & 2017 & Germany & $105 / 105$ & MBC & PFS & $1.08(0.76-1.54)$ \\
\hline
\end{tabular}


Abbreviations: STS, Soft tissue sarcoma; MM, Multiple myeloma; AML, Acute myelogenous leukaemia; NSCLC, Non-small cell lung cancer; OG, Oesophago-gastric; ALL, Acute lymphoblastic leukemia; MBC, Metastatic breast cancer; OC, Ovarian cancer; NA, Not available; OS, Overall survival; PFS, Progression-free survival; HR, hazard ratio; CI, confidence interval;

Table 3 Stratified analysis of liposomal doxorubicin-based chemotherapy

and overall survival.

\begin{tabular}{cccccccc}
\hline Categories & Subgroups & No & Case/Control & HR(95\%CI) & P-value & I2 & Ph \\
\hline All & & 26 & $3843 / 3911$ & $0.98(0.93-1.04)$ & 0.544 & $15.6 \%$ & 0.239 \\
Country & USA & 9 & $1330 / 1326$ & $0.91(0.79-1.06)$ & 0.217 & $51.0 \%$ & 0.038 \\
& UK & 5 & $331 / 363$ & $1.01(0.84-1.21)$ & 0.918 & $0.0 \%$ & 0.609 \\
& Greece & 3 & $293 / 283$ & $1.18(0.93-1.50)$ & 0.178 & $0.0 \%$ & 0.543 \\
Cancer types & Others & 9 & $1889 / 1939$ & $1.00(0.92-1.08)$ & 0.915 & $0.0 \%$ & 0.670 \\
& MBC & 9 & $1438 / 1455$ & $1.01(0.92-1.11)$ & 0.799 & $0.0 \%$ & 0.443 \\
& OC & 8 & $1692 / 1757$ & $0.94(0.86-1.02)$ & 0.132 & $35.1 \%$ & 0.148 \\
& NSCLC & 3 & $211 / 206$ & $1.16(0.92-1.47)$ & 0.215 & $0.0 \%$ & 0.620 \\
Sample sizes & Others & 6 & $502 / 493$ & $0.98(0.82-1.18)$ & 0.867 & $22.2 \%$ & 0.267 \\
& $\geqq 100$ & 18 & $3567 / 3620$ & $0.99(0.94-1.05)$ & 0.819 & $17.0 \%$ & 0.250 \\
& $<100$ & 8 & $276 / 291$ & $0.86(0.69-1.06)$ & 0.152 & $5.2 \%$ & 0.390 \\
\hline
\end{tabular}

Abbreviations: UK, The United Kingdom; NSCLC, Non-small cell lung cancer; MBC, Metastatic breast cancer;OC, Ovarian ca ncer; HR,Hazard ratio; CI, Confidence interval; Ph, P-value of heterogeneity test;

Table 4 Stratified analysis of liposomal doxorubicin-based chemotherapy

and progression-free survival.

\begin{tabular}{cccccccc}
\hline Categories & Subgroups & No & Case/Control & HR(95\%CI) & P-value & I2 & Ph \\
\hline All & & 27 & $3840 / 3908$ & $1.00(0.92-1.10)$ & 0.945 & $60.7 \%$ & 0.000 \\
Country & USA & 8 & $1234 / 1227$ & $1.04(0.83-1.31)$ & 0.720 & $82.1 \%$ & 0.000 \\
& UK & 6 & $411 / 443$ & $1.06(0.91-1.22)$ & 0.468 & $3.3 \%$ & 0.396 \\
& Greece & 4 & $386 / 379$ & $1.00(0.83-1.19)$ & 0.964 & $0.0 \%$ & 0.518 \\
Cancer types & Others & 9 & $1809 / 1859$ & $0.91(0.85-0.98)$ & 0.017 & $12.9 \%$ & 0.327 \\
& MBC & 9 & $1438 / 1455$ & $1.14(0.98-1.32)$ & 0.101 & $64.8 \%$ & 0.004 \\
& OC & 9 & $1689 / 1754$ & $0.87(0.81-0.94)$ & 0.000 & $14.1 \%$ & 0.316 \\
& NSCLC & 3 & $211 / 206$ & $0.84(0.68-1.03)$ & 0.086 & $0.0 \%$ & 0.800 \\
Sample sizes & Others & 6 & $502 / 493$ & $1.11(0.94-1.31)$ & 0.204 & $0.0 \%$ & 1.000 \\
& $\geqq 100$ & 18 & $3564 / 3617$ & $1.03(0.93-1.15)$ & 0.526 & $70.3 \%$ & 0.000 \\
& $<100$ & 9 & $276 / 291$ & $0.90(0.77-1.06)$ & 0.217 & $0.0 \%$ & 0.499 \\
\hline
\end{tabular}

Abbreviations: UK, The United Kingdom; NSCLC, Non-small cell lung cancer; MBC, Metastatic breast cancer;OC, Ovarian ca ncer; HR,Hazard ratio; CI, Confidence interval; Ph, P-value of heterogeneity test; 
Records identified through

English databases $(\mathbf{n}=98)$

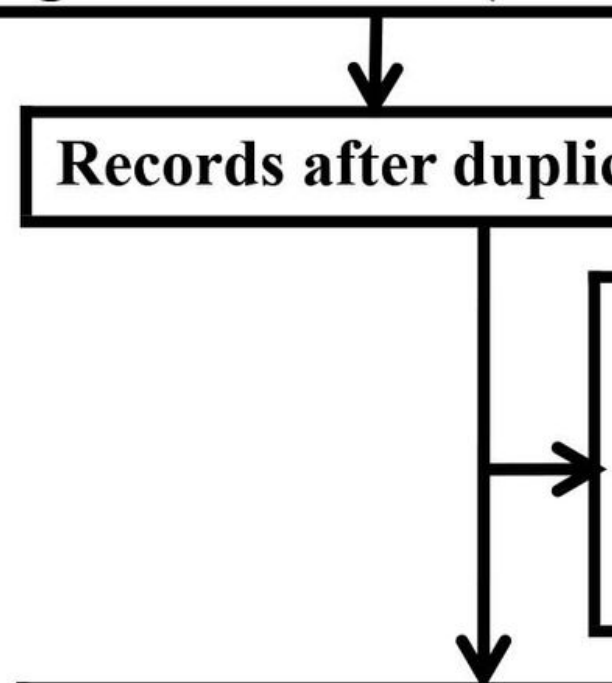

Records identified through

Chinese databases $(n=1)$

Records excluded on title and

abstract $(n=13)$

Reviews, Meta-analyses, Letters $(\mathbf{n}=\mathbf{6})$

Not-related studies $(n=7)$

Records about prognosis of liposomal

doxorubicin-based chemotherapy $(n=55)$

Not sufficient data $(n=24)$

Similar study $(\mathbf{n}=5)$

Records included meta-analysis $(\mathrm{n}=26)$

1 study containing three different groups

Records included meta-analysis $(\mathrm{n}=\mathbf{2 8})$

Figure 1

Flow diagram of the study selection process in the meta-analysis. 
HR

Studv or Subgroup log[HR] SE Weight IV, Fixed, 95\% Cl

\begin{tabular}{|c|c|c|c|c|}
\hline Alberts DS & -0.78 & 0.37 & $0.6 \%$ & $0.46[0.22,0.95]$ \\
\hline Baselga J & 0.24 & 0.13 & $4.9 \%$ & $1.27[0.99,1.64]$ \\
\hline Batist $\mathrm{G}$ & 0.04 & 0.15 & $3.7 \%$ & $1.04[0.78,1.40]$ \\
\hline Chan $\mathrm{s}$ & 0.14 & 0.21 & $1.9 \%$ & $1.15[0.76,1.74]$ \\
\hline Colombon & 0.07 & 0.08 & $13.0 \%$ & $1.07[0.92,1.25]$ \\
\hline Dimopoulos MA & 0.31 & 0.24 & $1.4 \%$ & $1.36[0.85,2.18]$ \\
\hline Gordon AN & -0.2 & 0.1 & $8.3 \%$ & $0.82[0.67,1.00]$ \\
\hline HarbeckN & 0.11 & 0.18 & $2.6 \%$ & $1.12[0.78,1.59]$ \\
\hline Harris L & -0.27 & 0.16 & $3.3 \%$ & $0.76[0.56,1.04]$ \\
\hline Hunault-Berger |w| & -0.03 & 0.3 & $0.9 \%$ & $0.97[0.54,1.75]$ \\
\hline Judson I & -0.45 & 0.27 & $1.1 \%$ & $0.64[0.38,1.08]$ \\
\hline Kaye SB-1 & -0.42 & 0.45 & $0.4 \%$ & $0.66[0.27,1.59]$ \\
\hline Kaye SB-2 & 0.01 & 0.42 & $0.5 \%$ & $1.01[0.44,2.30]$ \\
\hline Keller AM & 0.05 & 0.12 & $5.8 \%$ & $1.05[0.83,1.33]$ \\
\hline Latagliata $\mathrm{R}$ & -0.05 & 0.14 & $4.3 \%$ & $0.95[0.72,1.25]$ \\
\hline Wutch $\mathrm{DG}$ & 0.02 & 0.18 & $2.6 \%$ & $1.02[0.72,1.45]$ \\
\hline Mylonakis N & -0.08 & 0.27 & $1.1 \%$ & $0.92[0.54,1.57]$ \\
\hline O'Brien ME & -0.06 & 0.12 & $5.8 \%$ & $0.94[0.74,1.19]$ \\
\hline Pignata 5 & -0.2 & 0.11 & $6.9 \%$ & $0.82[0.66,1.02]$ \\
\hline Pujade-Lauraine E & -0.01 & 0.08 & $13.0 \%$ & $0.99[0.85,1.16]$ \\
\hline Rifkin RM & -0.37 & 0.41 & $0.5 \%$ & $0.69[0.31,1.54]$ \\
\hline Roy AC & 0.28 & 0.26 & $1.2 \%$ & $1.32[0.79,2.20]$ \\
\hline Smorenburg $\mathrm{CH}$ & -0.14 & 0.25 & $1.3 \%$ & $0.87[0.53,1.42]$ \\
\hline Sparano JA & -0.02 & 0.09 & $10.3 \%$ & $0.98[0.82,1.17]$ \\
\hline Stathopoulos GP & 0.19 & 0.17 & $2.9 \%$ & $1.21[0.87,1.69]$ \\
\hline $\operatorname{Yang} X$ & 0.24 & 0.23 & $1.6 \%$ & $1.27[0.81,2.00]$ \\
\hline (I) & & & $100.0 \%$ & $0.98[0.93,1.04]$ \\
\hline
\end{tabular}

IV, Fixed, $95 \% \mathrm{Cl}$

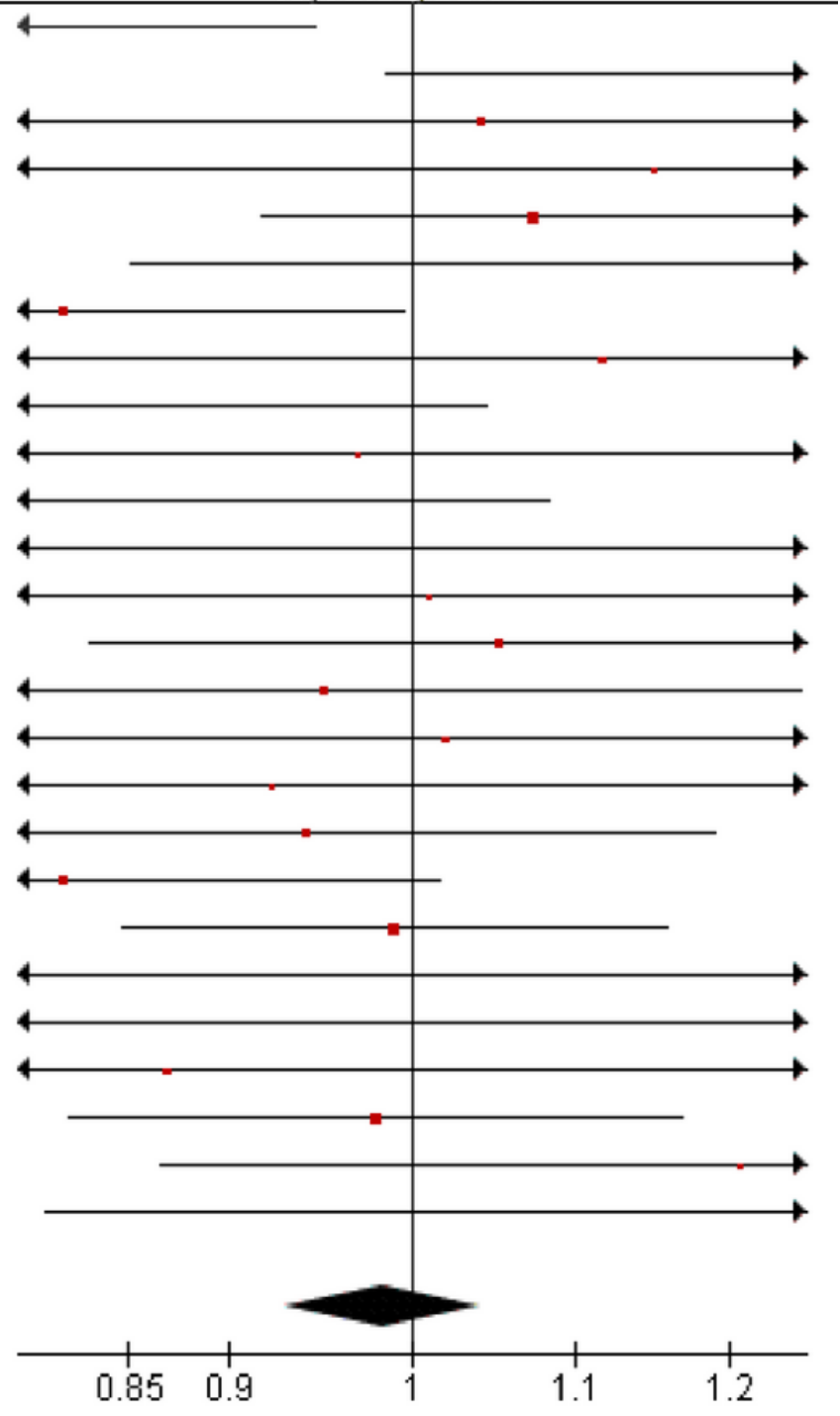

\section{Figure 2}

Forest plot of the association between liposomal doxorubicin-based chemotherapy in various tumors and OS. Notes: The squares and horizontal lines correspond to the study-specific HR and 95\% $\mathrm{Cl}$. The area of the squares reflects the weight. The diamond represents the summary $\mathrm{HR}$ and $95 \% \mathrm{Cl}$. Abbreviations: $\mathrm{Cl}$, confidence interval; HR, hazard ratio; OS, overall survival. 
HR

HR

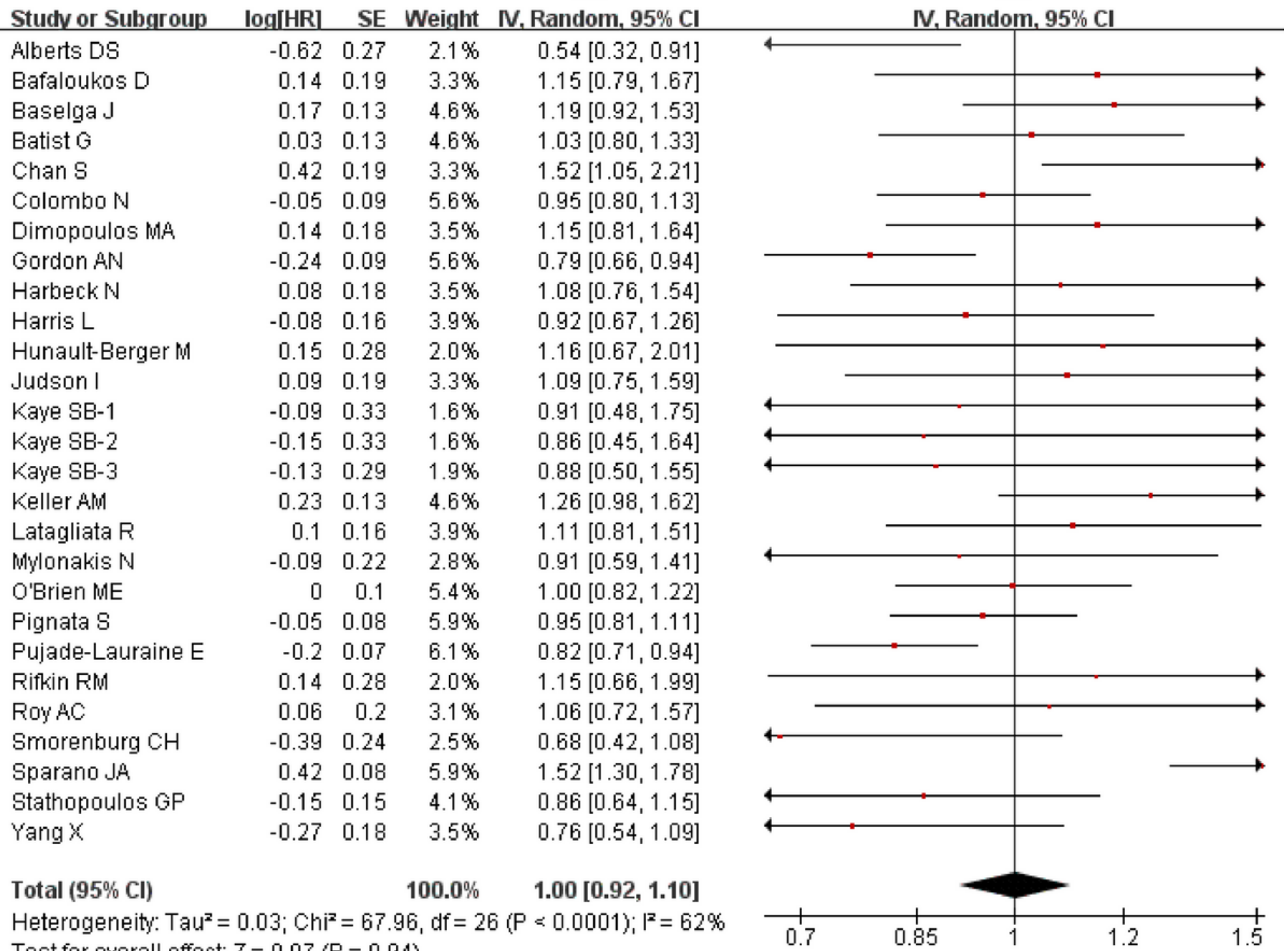

\section{Figure 3}

Forest plot of the association between liposomal doxorubicin-based chemotherapy in various tumors and OS. Notes:

The squares and horizontal lines correspond to the study-specific HR and $95 \% \mathrm{Cl}$. The area of the squares reflects the weight. The diamond represents the summary HR and $95 \% \mathrm{Cl}$. Abbreviations: $\mathrm{Cl}$, confidence interval; HR, hazard ratio; PFS, Progression-free survival. 
Meta-analysis estimates, given named study is omitted
| Lower Cl Limit
○stimate
Upper Cl Limit

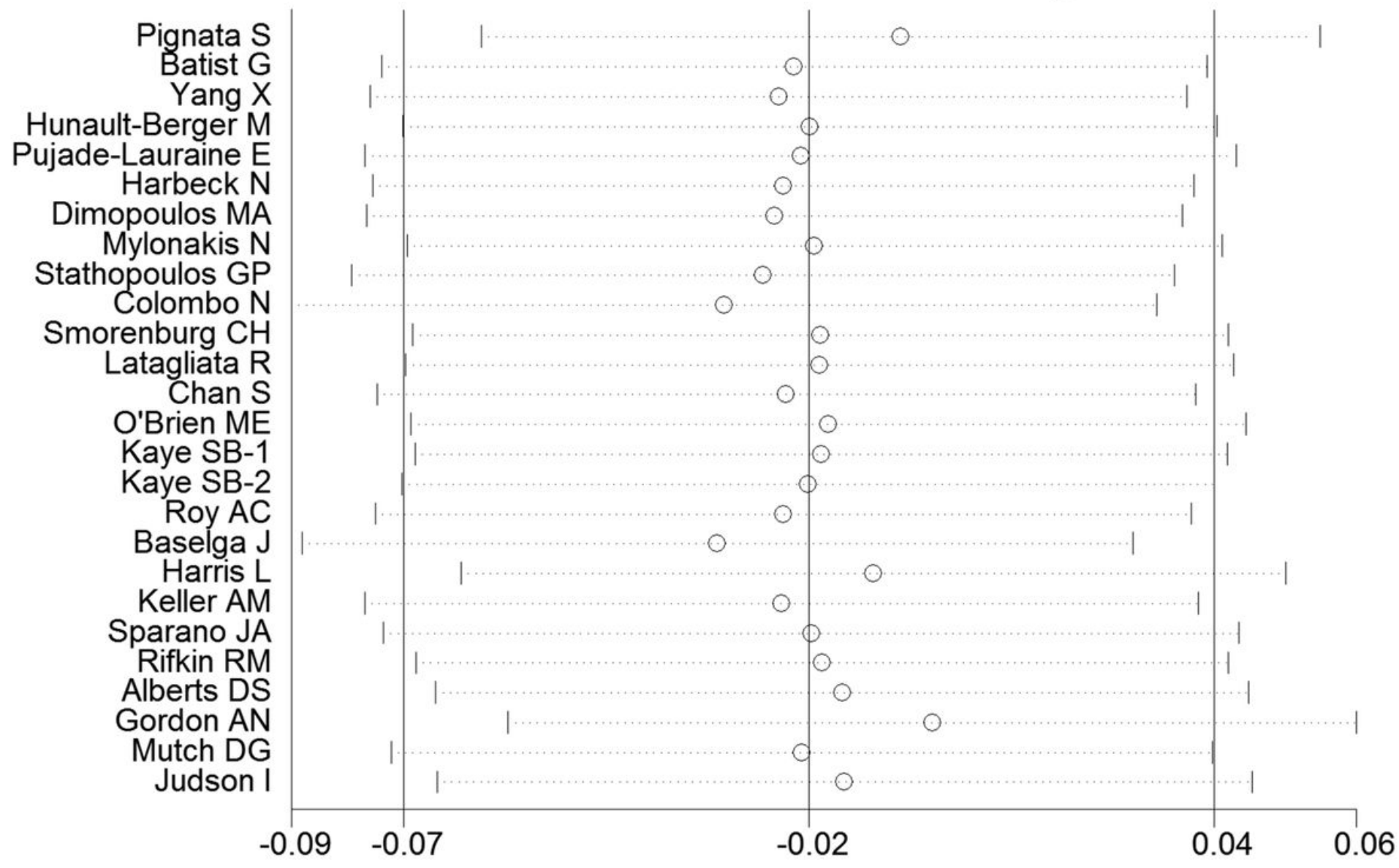

Figure 4

One-way sensitivity analysis of liposomal doxorubicin-based chemotherapy in various tumors with OS. Notes: Individually removed the studies and suggested that the results of this meta-analysis were stable. Abbreviations: OS, overall survival. 
Meta-analysis estimates, given named study is omitted

| Lower Cl Limit | Estimate Upper Cl Limit

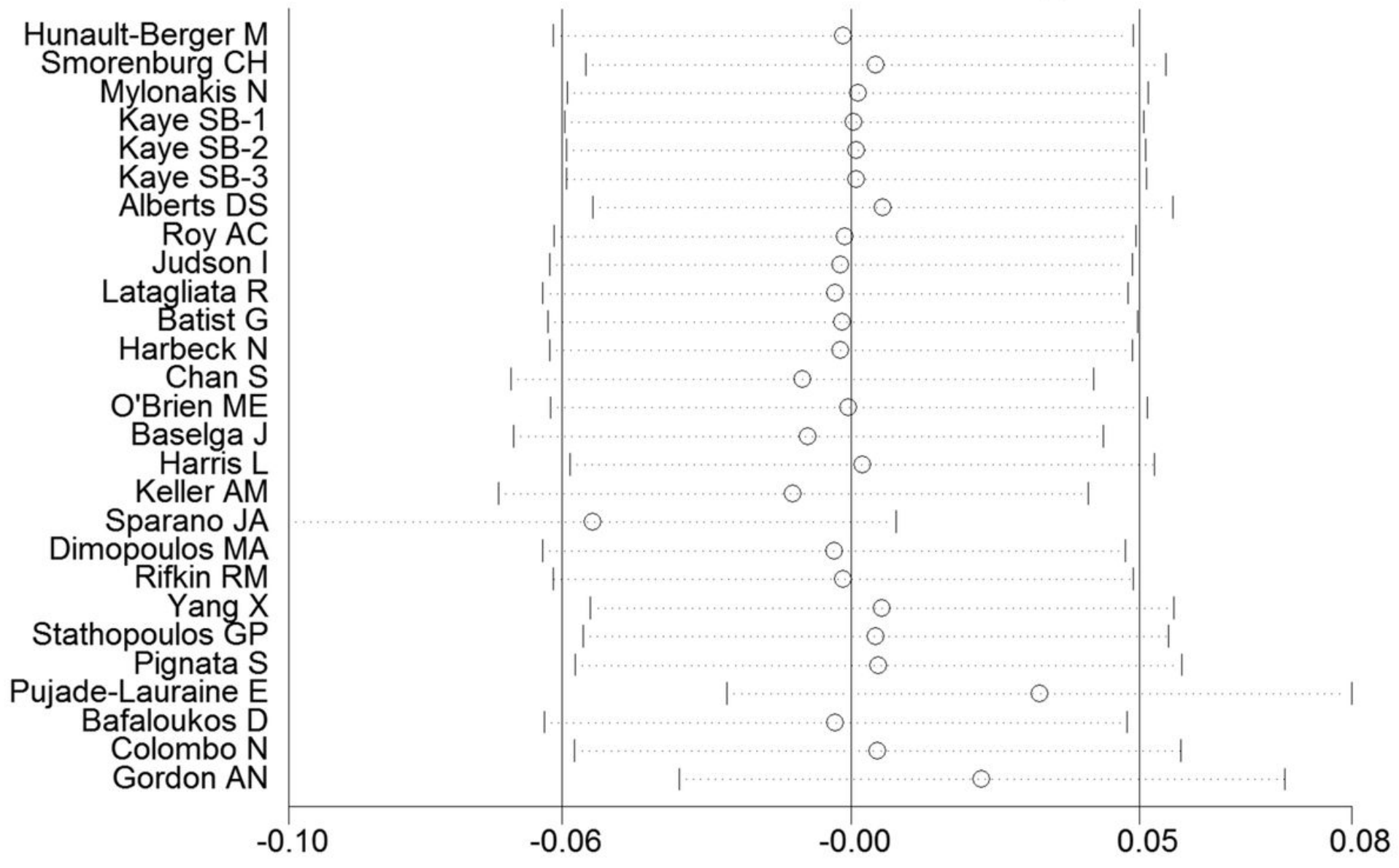

Figure 5

One-way sensitivity analysis of liposomal doxorubicin-based chemotherapy in various tumors with PFS. Note: Individually removed the studies and suggested that the results of this meta-analysis were stable. Abbreviations: PFS, Progression-free survival. 

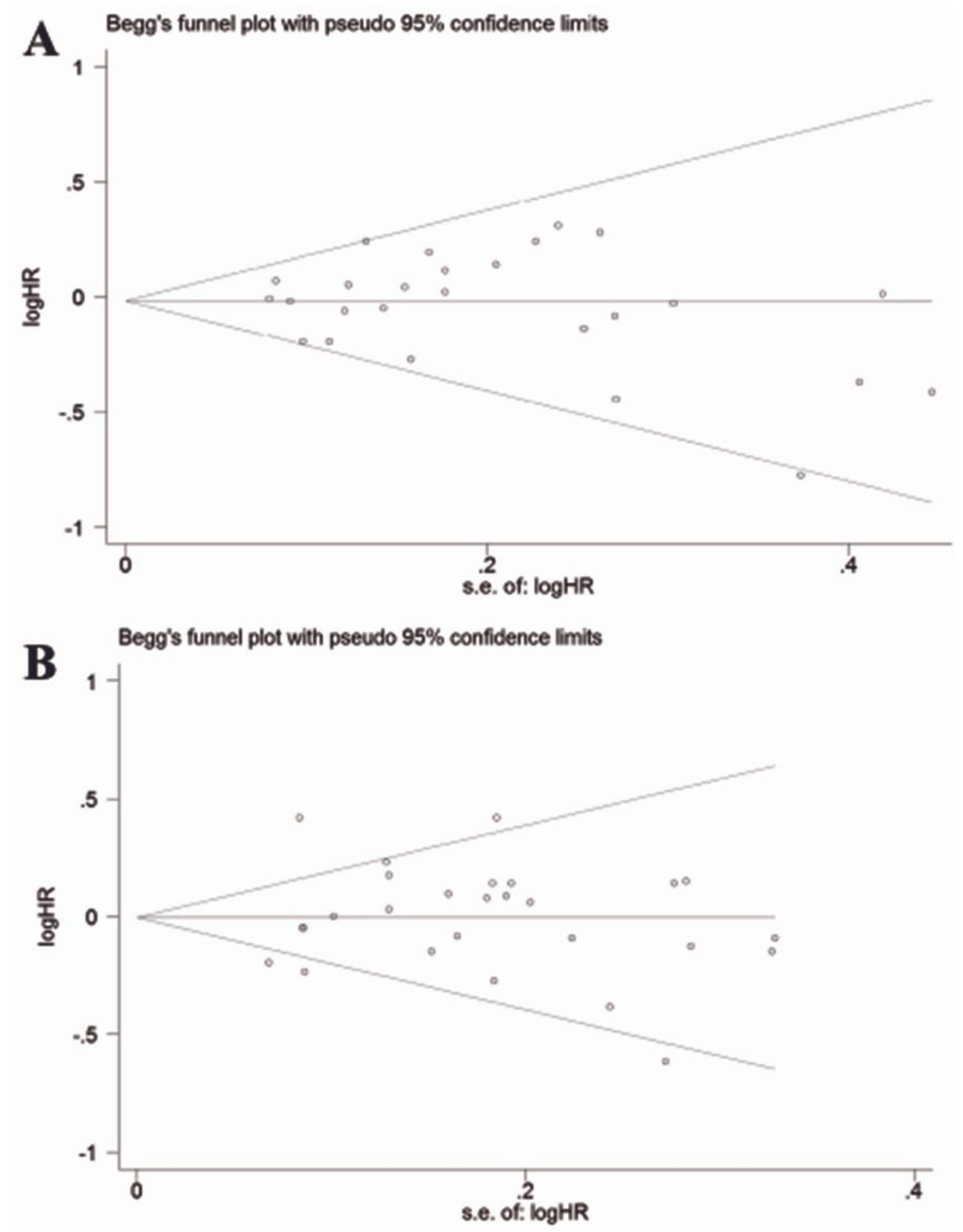

\section{Figure 6}

Begg's funnel plot for publication bias test. (A) OS of liposomal doxorubicin-based chemotherapy in various tumors; (B) PFS of liposomal doxorubicin-based chemotherapy in various tumors. Notes: The x-axis is log (HR), and the yaxis is natural logarithm of HR. The horizontal line in the figure represents the overall estimated log (HR). The two diagonal lines indicate the pseudo 95\% confidence limits of the effect estimate. Abbreviations: HR, hazard ratio; OS, overall survival; PFS, Progression-free survival. 